Jurnal Akuntansi dan Keuangan

FEB Universitas Budi Luhur

Vol. 10 No. 2 Oktober 2021

p-ISSN: 2252-7141

e-ISSN: 2622-5875

\title{
DETERMINAN EFISIENSI INVESTASI PADA PERUSAHAAN DI INDONESIA
}

\author{
Vina Pandu Wijaya \\ Ari Dewi Cahyati \\ Program Studi Akuntansi, Fakultas Ekonomi Universitas Islam 45 Bekasi $^{1,2}$ \\ Email: aridewicahyati@gmail.com ${ }^{2}$
}

\begin{abstract}
This purpose of this study was to determine the effect of corporate governance, ownership structure and debt maturity on investment efficiency. The sample in this study is a manufacturing sector company listed on the Indonesia Stock Exchange in 20152019. The sampling technique in this study uses the purposive sampling method, where there are 42 companies that meet predetermined criteria. Results of this study indicates that the audit committee has no effect and is not significant on investment efficiency, independent board of commissioners has a significant positive effect on investment efficiency, managerial ownership variable has no significant effect on investment efficiency, institutional ownership variable has no and no significant effect on investment efficiency, debt maturity variable has a significant positive effect on investment efficiency.
\end{abstract}

Keywords: corporate government, structure of ownership, debt maturity, investment efficiency.

\section{ABSTRAKSI}

Penelitian ini bertujuan untuk menguji pengaruh tata kelola perusahaan, struktur kepemilikan dan debt maturity terhadap efisiensi investasi. Sampel dalam penelitian ini adalah perusahaan sektor manufaktur yang terdaftar di BEI tahun 2015-2019.Teknik penarikan sampel dalam penelitian ini menggunakan metode purposive sampling, dimana terdapat 42 perusahaan yang memenuhi kriteria yang telah ditentukan. Hasil penelitian ini menunjukkan bahwa komite audit tidak berpengaruh dan tidak signifikan terhadap efisiensi investasi, variabel dewan komisaris independen berpengaruh positif signifikan terhadap efisiensi investasi, variabel kepemilikan manajerial tidak berpengaruh signifikan terhadap efisiensi investasi, variabel kepemilikan institusional tidak berpengaruh dan tidak signifikan terhadap efisiensi investasi, variabel debt maturity berpengaruh positif signifikan terhadap efisiensi investasi.

Kata kunci: Tata kelola, struktur kepemilikan, debt maturity, efisiensi investasi 


\section{PENDAHULUAN}

Setiap perusahaan memiliki tujuan yakni untuk memperoleh laba dari hasil usahanya, salah satu cara untuk memaksimalkan laba selain dari kegiatan operasional perusahaan yaitu dengan melakukan investasi. Investasi merupakan bentuk pengelolaan modal atau aset perusahaan dengan cara mengalokasikan modal atau aset tersebut pada proyek-proyek yang diperkirakan akan memberikan keuntungan dimasa mendatang. Umumnya investasi dibagi menjadi dua yakni investasi pada aset rill seperti pembelian aset produktif, pendirian pabrik, pembukaan pertambangan, pembukaan perkebunan, dan lain sebagainya (Abdul, 2005). Atau investasi pada aset keuangan seperti pembelian sertifikat deposito, surat berharga pasar uang, saham, obligasi, hak paten dan lain sebagainya (Abdul, 2005). Dalam berinvestasi, imbal balik (return) dan risiko (risk) akan selalu beriringan, dimana ada investasi yang memiliki risiko kerugian tinggi namun mampu menghasilkan imbal balik yang besar. Maka dari itu penting bagi manajer untuk membuat keputusan dalam berinvestasi agar perusahaan terhindar dari risiko dan kerugian, manajer harus membuat keputusan investasi yang tepat agar tercapai efisiensi investasi pada perusahaan.

Efisiensi investasi merupakan upaya yang dilakukan oleh perusahaan untuk menghemat sumber daya seminimal mungkin untuk mendapatkan hasil yang maksimal dari penanaman modal perusahaan agar tercapai tujuan perusahaan yang menguntungkan. Efisiensi investasi penting dilakukan agar tingkat investasi yang diharapkan oleh perusahaan tidak mengalami adanya penyimpangan atau tidak mengalami underinvestment dan overinvestment. Overinvestment ditandai dengan pengeluaran investasi yang melebih jumlah ekspektasi perusahaan, kondisi tersebut akan mengakibatkan perusahaan mengalami tingkat pertumbuhan yang lambat (slow growth), asset in place serta free cash flow yang tinggi,sementara underinvestment ditandai dengan pengeluaran investasi yang lebih sedikit dibandingkan dengan jumlah ekspektasi atau peluang yang ada karena perusahaan tidak memiliki cukup dana untuk membiayai suatu investasi. Efisiensi investasi berhubungan dengan adanya peningkatan penjualan atau sales growth, apabila penjualan suatu perusahaan semakin meningkat tentu menggambarkan laba yang semakin meningkat pula, sehingga manajer akan berfikir untuk memaksimalkan labanya dengan cara apapun termasuk investasi. Begitu juga sebaliknya apabila penjualan perusahaan menurun maka tingkat investasinya juga akan menurun. Efisiensi investasi yang tinggi menandakan penggunaan kas atau aset yang efisien dalam melakukan investasi. 
Fenomena efisiensi investasi telah terjadi di indonesia dalam (Kontan.co.id) dijelaskan bahwa tingkat efisiensi investasi di indonesia memburuk yang ditandai dengan tingginya angka Incremental Capital Output Ratio (ICOR). ICOR adalah perbandingan rasio antara tambahan modal atau investasi yang masuk dengan output atau hasil yang diperoleh, semakin tinggi ICOR semakin tidak efisien pula investasi. Dalam tahun 2011 sampai dengan 2019 angka Incremental Capital Output Ratio (ICOR) rata-rata negara di asean berada pada kisaran 3-4, sedangkan ICOR Indonesia berada pada kisaran 6 yang berarti bahwa tingkat efisiensi investasi di indonesia masih rendah, untuk mengatasi hal tersebut pemerintah menargetkan peningkatan peran investasi dalam PDB hingga di level $40 \%$ dalam jangka menengah panjang. Dengan cara mendorong industri pengolahan bahan baku penolong dan modal, serta menurunkan Incremental Capital Output Ratio (ICOR) atau tingkat efisiensi investasi.

Tingkat efisiensi investasi di indonesia memburuk dalam (CNBC Indonesia, 2020) dijelaskan bahwa sepanjang tahun 2019 industri sektor pengolahan atau manufaktur mengalami penurunan,hal tersebut dapat dilihat dari salah satu perusahaan yang terdaftar di bursa efek indonesia yakni salah satu pemimpin pasar otomotif di tanah air PT Astra International Tbk, laporan posisi keuangan konsolidasi pada periode 31 Desember 2019 PT Astra International Tbk meraih laba bersih Rp 21,71 triliun, laba bersih ini naik sebesar $0,18 \%$ dari tahun sebelumnya sebesar Rp 21,67 triliun, namun terjadi penurunan pendapatan sebesar $1 \%$ dari Rp 237,17 triliun, dibandingkan dengan tahun sebelumnya sebesar Rp 239,21 triliun. Hal ini juga tercermin dari tingkat efisiensi investasi yang telah diolah bahwa PT Astra International Tbk menunjukkan tingkat efisiensi investasi yang negatif sebesar $(-0,01)$ yang berarti perusahaan melakukan investasi yang lebih rendah dari investasi yang diharapkan sehingga perusahaan mengalami underinvestment. Presiden Direktur Astra Prijono Sugiarto menjelaskan kinerja grup selama tahun 2019 terimbas dari pelemahan konsumsi domestik dan rendahnya harga-harga komoditas. Lesunya penjualan kendaraan dalam negeri juga turut melemahkan kinerja indeks manufaktur ini. Mengutip data gabungan industri kendaraan bermotor Indonesia (GAIKINDO), selama Januari-November 2019, penjualan mobil nasional mencapai 940.362 unit atau turun $11,57 \%$ dibandingkan tahun lalu yang mencapai 1,06 juta unit mobil dilansir dari (investasi.kontan.co.id).

Bagi perusahaan aktivitas investasi memiliki risiko tinggi karena diperlukan perhitungan yang tepat, sehingga modal atau aset dapat di alokasikan untuk proyekproyek yang dapat menguntungkan perusahaan. Pemilihan proyek harus dilakukan secara tepat, jika tidak maka akan menimbulkan risiko kerugian bagi perusahaan. 
Investasi perusahaan yang dilakukan secara tepat dapat mencapai efisiensi. Investasi yang dilakukan dengan efisien akan mendatangkan keuntungan bagi perusahaan. Maka dari itu penting bagi manajer untuk membuat keputusan dalam berinvestasi yang tepat agar perusahaan terhindar dari risiko kerugian, manajer harus membuat keputusan investasi yang tepat agar tercapai efisiensi investasi pada perusahaan.

Dari kasus diatas dapat dilihat bahwa manager berperan penting dalam mengambil keputusan investasi karena selain berdampak pada kelangsungan perusahaan, keputusan yang dibuat manager dalam berinvestasi secara tidak langsung juga mempengaruhi tingkat efisiensi investasi di indonesia, maka dari itu berdasarkan teori keagenan,tindakan manajemen dapat diminimalisir melalui Good Corporate Governance (GCG) atau tata kelola perusahaan yang baik. Tata kelola perusahaan yang baik menjadi faktor utama dalam pertimbangan investor sebelum menanamkan modalnya kesuatu entitas karena dengan adanya GCG akan memperketat pengawasan terhadap keputusan yang diambil oleh pihak manajemen termasuk keputusan dalam berinvestasi. Good Corporate Governance (GCG) adalah suatu sistem terpadu yang menjaga hubungan antara pihak yang berkepentingan dalam pengelolaan suatu perusahaan sehingga adanya perusahaan tersebut memberikan dampak yang positif bagi seluruh pihak-pihak yang berkepentingan (Pasal 1/POJK/No.29/POJK.05/2020). Dalam penelitian ini beberapa faktor lain yang mempengaruhi tingkat efisiensi investasi diantaranya adalah tata kelola perusahaan didefinisikan dengan komite audit dan dewan komisaris independen, struktur kepemilikan didefinisikan oleh kepemilikan manajerial dan kepemilikan institusional serta debt maturity yang mana faktor-faktor tersebut akan membantu meningkatkan pengawasan terhadap manajemen dalam pengambilan keputusan investasi sehingga investasi yang dilakukan dapat semakin efisien.

Ada beberapa penelitian terdahulu yang membahas tentang efisiensi investasi, berdasarkan penelitian Simanungkalit (2017) komite audit berpengaruh terhadap efisiensi investasi, hal ini sejalan dengan penelitian Saputra dan Wardhani (2017), namun bertentangan dengan hasil penelitian (Nathaniel dan Butar, 2019). Penelitian Simanungkalit (2017) menemukan pengaruh positif dewan komisaris independen terhadap efisiensi investasi, namun bertentangan dengan hasil penelitian Nathaniel dan Butar (2019) dan Saputra dan Wardhani (2017), yang menyatakan independensi dewan komisaris tidak memengaruhi efisiensi investasi. Kepemilikan manajerial berpengaruh positif terhadap efisiensi investasi pada penelitian Simanungkalit (2017), sedangkan dalam penelitian Nathaniel dan Butar (2019) kepemilikan manajerial sebagai variabel kontrol berpengaruh negatif terhadap efisiensi investasi. Kepemilikan institusional tidak 
berpengaruh terhadap efisiensi investasi pada penelitian Simanungkalit (2017) dan Saputra dan Wardhani (2017) sedangkan dalam penelitian Nathaniel dan Butar (2019) kepemilikan institusional sebagai variabel kontrol berpengaruh negatif terhadap efisiensi investasi. Debt maturity berpengaruh positif terhadap efisiensi investasi dalam penelitian Christine dan Yanti (2017) dan Hutagalung (2017) namun bertentangan dengan penelitian Fransiska dan Triani (2016) yang menyatakan debt maturity tidak berpengaruh terhadap efisiensi investasi. Lai et al. (2013) meneliti hubungan tingkat disclosure dengan efiseiensi investasi dan menemukan bahwa semakin tinggi tingkat disclosure maka semakin baik juga efisiensi investaasi. Cao et al. (2018) dalam risetnya menemukan struktur kepemilikan khususnya kepemilikan instutusional berpengaruh positif terhadap efisiensi investasi pada perusahaan di Cina. Sedangkan Lei dan Chen (2018) menemukan bahwa corporate governance meningkatkan efisiensi investasi serta batasan hutang memperkuat pengaruh corporate governance terhadap efisiensi investasi

Penelitian ini menguji faktor penentu efisiensi investasi dimana faktor-faktor penentunya adalah corporate government, structure of ownership, dan debt maturity. Proksi untuk mengukur corporate governace adalah komite audit, dewan komisaris independen. Sedangkan proksi untuk mengukur stuktur kepemilikan adalah kepemilikan manajerial dan kepemilikan institusional sedangkan debt maturity diproksikan dengan rasio utang jangka pendek atau terhadap total utang. Penelitian ini menggunakan sampel seluruh perusahaan manufaktur yang terdaftar di BEI periode 2015 - 2019. Perusahaan manufaktur menjadi objek dalam penelitian ini dikarenakan perusahaan sektor manufaktur merupakan penyedia kebutuhan primer dan sekunder terbesar bagi masyarakat selain itu sektor manufaktur berperan penting dalam upaya menggenjot nilai investasi dan ekspor sehingga menjadi sektor andalan untuk mengakselerasi pertumbuhan ekonomi indonesia, selain itu aktivitas industri ini senantiasa konsisten memberikan efek berantai yang luas bagi perekonomian baik di daerah maupun nasional. Dapat dilihat bahwa sektor manufaktur memberikan dampak besar yang dapat mendorong pertumbuhan ekonomi Indonesia, sehingga pihak manajemen perusahaan akan berhati-hati dalam mengambil keputusan investasi agar terhindar dari kesalahan dan terciptanya efisiensi investasi serta diharapkan hasil penelitian ini dapat relevan. 


\section{TINJAUAN PUSTAKA}

\section{Teori Agensi (Agency Theory)}

Jensen and Meckling (1976) menjelaskan hubungan keagenan terdiri atas dua pihak yang terlibat dalam menjalankan sebuah entitas, baik organisasi laba maupun nirlaba. Pihak- pihak tersebut dikenal dengan principal dan agent. Pihak principaladalah pemilik dari sebuah entitas yang kemudian dijalankan oleh seorang agen, yang kemudian pihak agen ini dalam menjalankan perusahaannya seharusnya sesuai dengan keinginan pemilik (principa). Masalah akan timbul saat kepentingan dari kedua pihak berbeda. Konflik kepentingan antara pemilik dan agen terjadi karena kemungkinan agen tidak selalu berbuat sesuai dengan kepentingan principal. Perilaku manajemen dapat dijelaskan dengan teori keagenan ini (Suwardjono, 2014). Terdapat dua macam asimetri informasi, yaitu adverse selection dan moral hazard (Scott, 2000). Berkaitan dengan moral hazard kurangnya proses monitoring akan membawa manajemen mengambil keputusan yang tidak seluruhnya diketahui oleh pemegang saham, sehingga manajemen dapat melakukan tindakan penyimpangan dalam hal investasi bisa dengan diambilnya proyek- proyek yang tidak sesuai ekspektasi perusahaan atau investasi berlebih dengan tujuan untuk menghasilkan keuntungan untuk mereka sendiri atau terjadinya overinvestment. Sedangkan adverse selection menyatakan bahwa manajemen lebih mengetahui informasi tentang perusahaan dibanding pihak investor sehingga semakin baik informasi dari manajemen maka manajemen akan berpeluang untuk memaksimalkan keuntungan perusahaan untuk diri mereka sendiri yaitu dengan tidak memaksimalkan investasi prinsipal pada perusahaan yang berdampak pada tidak diambilnya proyek yang bisa meningkatkan keuntungan perusahaan atau terjadinya underinvestment. Untuk menghindari moral hazard dan adverse selection maka diperlukan suatu mekanisme tata kelola perusahaan. Tata Kelola Perusahaan atau Good Corporate Governance (GCG) adalah suatu sistem yang digunakan dan diterapkan perusahaan untuk meningkatkan pencapaian sasaran hasil usaha dan mengoptimalkan nilai perusahaan bagi seluruh pemangku kepentingan secara akuntabel dan berlandaskan peraturan perundang-undangan serta nilai-nilai etika (Pasal 1/POJK/NOMOR 29/POJK.05/2020).

\section{Pengaruh Komite Audit terhadap Efisiensi Investasi}

Komite audit adalah salah satu bagian dari mekanisme tata kelola perusahaan, yang bertugas untuk melakukan evaluasi dan audit laporan keuangan perusahaan, menurut Ikatan Komite Audit yang dikutip oleh Arief (2009), komite audit sebagai suatu 
komite yang bekerja secara profesional dan independen yang di bentuk oleh dewan komisaris dengan demikian tugasnya adalah membantu dan memperkuat fungsi dewan komisaris (atau dewan pengawas) dalam menjalankan fungsi pengawasan (oversight) atas proses pelaporan keuangan, manajemen risiko, pelaksanaan audit dan implementasi dari corporate governance di perusahaan-perusahaan.

Tugas pokok dari komite audit pada prinsipnya adalah membantu dewan komisaris dalam melakukan fungsi pengawasan. Tugas komite audit juga erat kaitannya dengan sistem pengendalian internal termasuk tentang penelaahan terhadap risiko yang dihadapi perusahaan, dan juga kepatuhan terhadap regulasi. Termasuk resiko dalam mengambil keputusan investasi, dengan adanya komite audit pihak manajer akan merasa diawasi dan berhati-hati dalam mengambil keputusan investasi agar teciptanya tingkat investasi yang efisien dan membawa keuntungan bagi perusahaan dan para pemegang saham. Berdasarkan uraian diatas maka penelitian ini mengambil hipotesis sebagai berikut:

H1: komite audit berpengaruh positif terhadap efisiensi investasi

\section{Pengaruh Komisaris Independen terhadap Efisiensi Investasi}

Selain komite audit mekanisme GCG yang lain adalah berfungsinya komisaris independen memiliki peranan penting dalam melakukan pengawasan terhadap kegiatan usaha (bisnis) perusahaan. Berdasarkan Peraturan Otoritas Jasa Keuangan (POJK/Nomor.29/POJK.05/2020) Komisaris independen memiliki fungsi pengawasan dan pemberian nasihat kepada direksi secara efektif agar lebih memberikan nilai tambah bagi perusahaan serta memastikan transparansi laporan keuangan perusahaan dan mengawasi praktek manajemen dalam melakukan proses penyusunan laporan keuangan. Dengan demikian apabila jumlah dewan komisaris independen memadai dan berfungsi dengan baik maka pihak agen akan merasa diawasi dalam setiap tindakan dan keputusannya sehingga manajer akan mengelola perusahaan sesuai dengan ketentuan dan keinginan pihak prinsipal dan berhati-hati dalam mengambil keputusan, hal ini akan berdampak baik bagi pengambilan keputusan investasi perusahaan yang semakin efisien. Saputra dan Wardhani (2017) dan Simanungkalit (2017) menjelaskan dewan komisaris independen berpengaruh positif signifikan terhadap efisiensi investasi perusahaan. Berdasarkan penjelasan diatas maka diturunkan hipotesis sebagai berikut: $\mathrm{H} 2$ : dewan komisaris independen berpengaruh positif terhadap efisiensi investasi 


\section{Pengaruh Kepemilikan Manajerial terhadap Efisiensi Investasi}

Permasalahan teori agensi antara pihak manajemen dan pihak investor yaitu adanya konflik kepentingan yang disebut dengan moral hazard yang mana pihak manajemen lebih mengetahui informasi mengenai perusahaan dari pada pihak pihak investor (Jensen dan Meckling,1976), namun konflik ini dapat diminimalisir bila manajer mempunyai kepemilikan atas saham perusahaan. Apabila kepemilikan saham manajerial tinggi maka manajerial akan berusaha semaksimal mungkin untuk menghasilkan keuntungan dari kepemilikan saham diperusahaan yang dikelolanya tersebut. Sehingga keputusan yang diambil akan memperhatikan kepentingan pihak agen dan investor, termasuk keputusan dalam berinvestasi sehingga keputusan investasi yang dilakukan dapat semakin efisien (Gregoric, 2004; Simanungkalit, 2017). Berdasarkan penjelasan diatas maka hipotesis penelitian ini sebagai berikut:

H3: kepemilikan manajerial berpengaruh positif terhadap efisiensi investasi.

\section{Pengaruh Kepemilikan Institusional terhadap Efisiensi Investasi}

Pengaruh kepemilikan institusional terhadap efisiensi investasi Teori agensi menyatakan bahwa dalam suatu perusahaan terbagi antara pihak prinsipal yaitu pemilik dan agen yaitu manajer. Dalam hubungan keduanya sering kali tak terhindarkan konflik kepentingan. Dimana manajer lebih mengetahui secara dalam kondisi perusahaan dari pada prinsipal (Jensen dan Meckling, 1976). Hal ini akan berpeluang agen akan memaksimalkan keuntungan perusahaan untuk diri mereka sendiri yaitu dengan tidak memaksimalkan 24 investasi prinsipal pada perusahaan yang berdampak pada tidak diambilnya proyek yang bisa meningkatkan keuntungan perusahaan. Peran dari investor institusional mampu memberikan keselarasan kepentingan antara manajemen dan para pemilik saham. Dengan adanya keterlibatan pemilik institusi maka dapat menyeimbangkan wewenang yang dimiliki manajer dengan pihak pemegang saham eksternal. Selain itu, kepemilikan saham oleh institusi merupakan hal yang penting dalam metode monitoring agent yang memberikan peranan secara aktif dan konsisten dalam pengawasan perusahaan atas investasi yang ditanamkan. Sehingga efisiensi investasi yang dilakukan perusahaan dapat terealisasi. Dengan demikian dapat dikatakan terdapat pengaruh antara kepemilikan institusional terhadap efisiensi investasi (Zheka, 2003). Berdasarkan penjelasan diatas maka hipotesis penelitian adalah sebagai berikut:

H4: kepemilikan institusional berpengaruh positif terhadap efisiensi investasi. 


\section{Pengaruh Debt Maturity terhadap Efisiensi Investasi}

Debt maturity merupakan kebijakan penentuan jatuh tempo utang yang dilakukan oleh perusahaan. Dalam penelitian ini menggunaan kebijakan utang jangka pendek atau short debt maturity yang mana dapat meningkatkan pengawasan terhadap manajemen. Hal ini disebabkan penggunaan utang jangka pendek yang lebih besar dapat meningkatkan pengendalian dan pengawasan kreditur terhadap manajer karena negosiasi ulang lebih sering terjadi sehingga pihak pemberi pinjaman lebih sering bertemu dengan penerima pinjaman yang membuat manajer merasa diawasi sehingga manajemen akan bekerja secara maksimal dan berhati-hati dalam mengambil keputusan yang tepat termasuk dalam mengelola dana investasi pada perusahaan dengan demikian keputusan investasi yang dibuat akan semakin efisiensi (Gomeris et al., 2014 dalam Nathaniel \& Butar-butar, 2019). Hal ini sejalan dengan penelitian yang dilakukan oleh Hutagalung (2017), Christine dan Yanti (2017) yang menyatakan debt maturity berpengaruh positif terhadap efisiensi investasi. Berdasarkan penjelasan diatas maka penelitian ini mengambil hipotesis sebagai berikut:

H5: debt maturity berpengaruh positif terhadap efisiensi investasi.

\section{METODE PENELITIAN}

Penelitian ini menggunakan metode penelitian kuantitatif dengan dengan jenis penelitian explanatory research untuk menguji ada atau tidaknya pengaruh komite audit,dewan komisaris independen,kepemilikan manajerial,kepemilikan institutional dan debt maturity terhadap efisiensi investasi. Penelitian ini menerapkan model hubungan fungsional antara variable independen dengan variabel dependen yang diestimasi menggunakan model regresi linear berganda dengan hipotesis sebagai berikut:

$$
Y=A+B 1 K A+B 2 D K I+B 3 K M+B 4 K I+B 5 D M+E
$$

\section{Keterangan:}

$\mathrm{Y} \quad=$ Efisiensi Investasi

$\mathrm{KA}=$ Komite Audit

DKI = Dewan Komisaris Independen

$\mathrm{KM} \quad=$ Kepemilikan Manajerial

$\mathrm{KI}=$ Kepemilikan Institutional

DB = Debt Maturity

A $\quad=$ Konstanta

B1-B4 = Koefisien Regresi

$\mathrm{E} \quad=$ Error atau Kesalahan 
Sampel penelitian ini ditentukan dengan metode purposive sampling. Sampel yang digunakan merupakan perusahaan yang bergerak dalam sektor manufaktur yang terdaftar di Bursa Efek Indonesia (BEI) dengan periode penelitian dari tahun 2015-2019. Sampel yang dipilih merupakan sampel yang memiliki kriteria-kriteria berikut:

\section{Tabel 1. Kriteria Penelitian Sampel}

\begin{tabular}{llr}
\hline No & \multicolumn{1}{c}{ Kriteria } & Jumlah \\
\hline $1 \quad \begin{array}{l}\text { Perusahaan manufaktur yang terdaftar secara terus menerus di BEI dari } \\
\text { tahun 2015-2019 }\end{array}$ & 138 \\
$2 \quad \begin{array}{l}\text { Perusahaan yang tidak menggunakan mata uang rupiah dilaporan } \\
\text { keuangan tahun 2015-2019 }\end{array}$ & $(27)$ \\
3. Perusahaan yang tidak menerbitkan laporan keuangan yang telah diaudit & $(2)$ \\
$\quad \begin{array}{l}\text { tahun 2015-2019 kerusahaan yang tidak memiliki data yang dibutuhkan peneliti seperti } \\
\text { data komite audit, komisaris independen,kepemilikan }\end{array}$ & \\
$\quad \begin{array}{l}\text { manajerial,kepemilikan institusional, debt maturity dan data efisiensi } \\
\text { investasi dari tahun 2015-1019 }\end{array}$ & \\
Jumlah perusahaan yang digunakan & 42 \\
5 tahun pengamatan (dikali lima) & 58 \\
Data outlier & 142 \\
Jumlah sampel & \\
\hline
\end{tabular}

Sumber: data sekunder yang diolah, 2021

Tabel 2. Variabel dan Pengukuran

\begin{tabular}{|c|c|c|c|}
\hline Variabel dan Sumber & Pengukuran & Skala & Data \\
\hline $\begin{array}{l}\text { Komite audit (X1) } \\
\text { Simanungkalit (2017) }\end{array}$ & Jumlah komite audit & Nominal & $\begin{array}{l}\text { Laporan } \\
\text { Keuangan }\end{array}$ \\
\hline $\begin{array}{l}\text { Dewan komisaris } \\
\text { Independen (X2) } \\
\text { Simanungkalit (2017) }\end{array}$ & $\begin{array}{l}\text { Jumlah komisaris } \\
\text { independen/total dewan } \\
\text { komisaris }\end{array}$ & Rasio & $\begin{array}{l}\text { Laporan } \\
\text { Keuangan }\end{array}$ \\
\hline $\begin{array}{l}\text { Kepemilikan manajerial (X3) } \\
\text { Simanungkalit (2017) }\end{array}$ & $\begin{array}{l}\text { Total saham manajerial / total } \\
\text { saham beredar } \times 100 \%\end{array}$ & Rasio & $\begin{array}{l}\text { Laporan } \\
\text { Keuangan }\end{array}$ \\
\hline $\begin{array}{l}\text { Kepemilikan instutional(X4) } \\
\text { Simanungkalit (2017) }\end{array}$ & $\begin{array}{l}\text { Total saham instutional/ total } \\
\text { saham beredar } \times 100 \%\end{array}$ & Rasio & $\begin{array}{l}\text { Laporan } \\
\text { Keuangan }\end{array}$ \\
\hline $\begin{array}{l}\text { Debt maturity (X5) } \\
\text { Nathaniel dan Butar (2019) }\end{array}$ & $\begin{array}{l}\text { Utang jangka pendek / total } \\
\text { utang }\end{array}$ & Rasio & $\begin{array}{l}\text { Laporan } \\
\text { Keuangan }\end{array}$ \\
\hline $\begin{array}{l}\text { Efesiensi investasi }(Y) \\
\text { Hutagalung(2017) }\end{array}$ & $\begin{array}{l}\text { Regresi linear sederhana } \\
\text { persamaan residual (investasi- } \\
\text { pertumbuhan penjualan) }\end{array}$ & Rasio & $\begin{array}{l}\text { Laporan } \\
\text { Keuangan }\end{array}$ \\
\hline
\end{tabular}




\section{HASIL PENELITIAN DAN PEMBAHASAN}

\section{Analisis Koefisien Determinasi}

Tabel 3. Hasil Uji Koefisien Determinasi (R2)

\begin{tabular}{lrrrrr}
\hline \multicolumn{5}{c}{ Model Summary $^{\mathbf{b}}$} \\
\hline Model & R & \multicolumn{2}{c}{ R Square } & Adjusted R Square & Std. Error Of The Estimate \\
\hline 1 & &, $678^{\text {a }}$ &, 459 &, 439 &, 05238 \\
\hline Sumber : Hasil Output SPSS 25,2021 & &
\end{tabular}

Dari hasil pengolahan koefisien determinasi adjustr square $=0,439$, artinya komite audit, dewan komisaris independen, kepemilikan manajerial, kepemilikan institusional dan debt maturity mampu menjelaskan variansi dari efisiensi investasi adalah sebesar $43,9 \%$. Sisanya $56,1 \%$ dijelaskan oleh variabel lain selain dari penelitian ini.

\section{Uji F (Uji Goodness of Fit)}

Tabel 4. Hasil Uji F

\begin{tabular}{llrrrrr}
\hline Model & Sum of Squares Df & \multicolumn{3}{c}{ Mean Square } & \multicolumn{2}{c}{ Sig. } \\
\hline \multicolumn{1}{c}{ Regression } &, 317 & 5 &, 063 & 23,097 &, $000^{\mathrm{b}}$ \\
1 & Residual &, 373 & 136 &, 003 & & \\
& Total &, 690 & 141 & & & \\
\hline
\end{tabular}

Sumber: Hasil Output SPSS 25,2021

Berdasarkan tabel uji $F$ diatas, bahwa $F$ hitung sebesar 23,097 dan $F$ tabel sebesar 2,28 dan nilai signifikansi nya sebesar 0,000. artinya $F$ hitung 23,097 > F tabel 2,28 dan nilai signifikansinya $0,000<0,05$. Sehingga disimpulkan bahwa model yang digunakan dalam penelitian ini fit.

\section{Uji t}

\section{Tabel 5. Hasil Uji t}

\begin{tabular}{|c|c|c|c|c|c|c|}
\hline & \multirow{2}{*}{ Model } & \multicolumn{2}{|c|}{ Unstandardized Coefficients } & \multirow{2}{*}{$\begin{array}{c}\text { Standardized Coefficients } \\
\text { Beta }\end{array}$} & \multirow{2}{*}{$\mathrm{t}$} & \multirow{2}{*}{ Sig. } \\
\hline & & B & Std. Error & & & \\
\hline \multirow{6}{*}{1} & (Constant) & 1,393 & ,036 & & 38,842 & 000 \\
\hline & KA &,- 017 & 010 & -107 & $-1,636$ & 104 \\
\hline & DKI & 212 & 050 & 276 & 4,242 & 000 \\
\hline & KM &,- 058 & ,025 & -177 & $-2,311$ & ,022 \\
\hline & KI &,- 020 & 021 & -,067 & -918 & 360 \\
\hline & $D M$ & 029 & 004 & 690 & 8,081 & 000 \\
\hline
\end{tabular}

Sumber: Hasil Output SPSS 25,2021

\section{Interpretasi Hasil Penelitian}

Berdasarkan hasil pengujian data diatas,maka dapat diperoleh persamaan regresi linear berganda sebagai berikut :

$\mathrm{Y}=1,393 \mathrm{a}-0,017 \mathrm{KA}+0,212$ DKI-0,058 KM -0,020 KI +0,029 DM

selanjutnya Hasil penelitian dibahas sebagai berikut: 


\section{Pengaruh Komite Audit terhadap Efisiensi Investasi}

Hasil uji statistik menyatakan bahwa komite audit tidak berpengaruh secara signifikan terhadap efisiensi investasi. Hasil ini bisa dilihat dari nilai signifikansi untuk komite audit 0,104 > 0,05 dan thitung $-1,636>$ dari t tabel $-1,977$. Hal ini didukung oleh penelitian yang dilakukan Nathaniel, Butar-Butar (2019) yang menyatakan komite audit tidak berpengaruh terhadap efisiensi investasi. Penelitian ini tidak sejalan dengan teori agency yang menyatakan bahwa hubungan keagenan antara agent (manajemen) dengan principal (pemegang saham) akan menimbulkan asimetrri informasi yang mendorong pihak manajemen melakukan moral hazard, agar pihak manajemen tidak melakukan moral hazard maka diperlukan mekanisme pengawasan yaitu tata kelola dimana salah satunya adalah berfunsinya komite audit dalam perusahaan. Tugas pokok dari komite audit pada prinsipnya adalah membantu dewan komisaris dalam melakukan fungsi pengawasan. Tugas komite audit juga erat kaitannya dengan sistem pengendalian internal termasuk tentang penelaahan terhadap risiko yang dihadapi perusahaan, dan juga kepatuhan terhadap regulasi. Selain itu komite audit juga memiliki wewenang kepada tim audit internal perusahaan untuk menelusuri tentang kinerja dan kesungguhan kualitas kinerja perusahaan, sehingga manajer akan selalu merasa diawasi dan akan berdampak pada keputusan yang akan dibuat manajer termasuk keputusan dalam berinvestasi sehingga keputusan investasi yang diambil akan semakin efisien sesuai dengan apa yang diharapkan perusahaan. Berdasarkan penjelasan diatas maka dapat disimpulkan bahwa fungsi pengawasan yang dilakukan komite audit hanya fokus terhadap penelaahan atas informasi keuangan yang akan dikeluarkan perusahaan kepada publik dan pihak otoritas antara lain laporan keuangan, proyeksi, dan laporan lainnya terkait dengan informasi keuangan perusahaan dan melakukan penelaahan atas ketaatan terhadap peraturan perundang-undangan yang berhubungan dengan kegiatan perusahaan (IKAI), sehingga di dalam rapat komite audit tidak membahas mengenai proyek-proyek investasi secara khusus.

\section{Pengaruh Komisaris Independen terhadap Efisiensi Investasi}

Hasil pengujian statistik menemukan bahwa dewan komisaris independen berpengaruh positif terhadap efisiensi investasi pada perusahaan manufaktur yang terdaftar di BEI tahun 2015-2019. Berdasarkan tabel 5 diketahui bahwa t hitung 4,242 $>$ dari t tabel 1,977 dengan tingkat signifikansi untuk dewan komisaris independen $=$ $0,000<0,05$. Hasil ini didukung oleh penelitian yang dilakukan Simanungkalit (2019) yang menyatakan jumlah dewan komisaris berpengaruh positif signifikan terhadap 
efisiensi investasi dimana dewan komisaris yang tidak memiliki afiliasi bisnis dengan perusahaan tersebut mampu memberikan kontribusi penilaian dan pemberi masukan terhadap kinerja perusahaan yang sesuai dengan kebutuhan perusahaan. semakin banyak komisaris independen, semakin banyak masukan yang di diperoleh. Apabila kinerjanya sudah maksimal, maka laporan keuangan yang dihasilkan juga berkualitas karena laporan keuangan dihasilkan sesuai dengan pengawasan dewan komisaris dan kinerja perusahaan mengalami peningkatan kualitas sehingga akan meningkatkan efisiensi investasi perusahaan. Hal ini didukung oleh penelitian yang dilakukan oleh Szczepankowski (2012) yang menyatakan bahwa terdapat pengaruh positif komisaris independen terhadap efisiensi investasi perusahaan. Pemikiran ini didukung hasil penelitian Vafeas (2000) dan Anderson et al. (2003).

\section{Pengaruh Kepemilikan Manajerial terhadap Efisiensi Investasi}

Berdasarkan tabel 5 diketahui bahwa t hitung -2,311< dari t tabel -1,977 dengan tingkat signifikansi untuk kepemilikan manajerial $=0,022<0,05$, maka disimpulkan bahwa kepemilikan manajerial berpengaruh negatif terhadap efisiensi investasi. Hasil ini didukung oleh penelitian yang dilakukan Nathaniel, Butar-Butar (2019) yang menyatakan kepemilikan manajerial berpengaruh negatif terhadap efisiensi investasi. Artinya kepemilikan manajerial yang tinggi akan menurunkan efisiensi investasi. Hal ini juga tidak sesuai dengan teori Agensi, teori agensi menyatakan bahwa semakin tinggi kepemilikan manajerial akan pihak manajemen akan lebih giat memenuhi kepentingan manajemen yang merupakan dirinya sendiri termasuk melakukan efisiensi terhadap investasi yang dilakukan. Kondisi ini disebabkan karena rata-rata perusahaan manufaktur yang menjadi sampel dalam penelitian ini memiliki jumlah kepemilikan manajerial yang sangat rendah dan dalam rapat pengambilan keputusan masih didominasi oleh pemilik diluar manajemen karena kepemilikan saham oleh pihak manajemen masih kecil. Dengan demikian hasilnya kurang dapat digunakan untuk menunjukkan bahwa kepemilikan manajerial dapat mempengaruhi efisiensi investasi perusahaan.

\section{Pengaruh Kepemilikan Institusional terhadap Efisiensi Investasi}

Hasil pengujian statistik mengindikasikan kepemilikan institusional tidak berpengaruh terhadap efisiensi investasi. Hal ini didukung oleh penelitian yang dilakukan Azhar dkk (2019) dan Simanungkalit (2019) yang menyatakan pengawasan yang dilakukan oleh investor institusional tidak dilakukan secara efektif untuk menciptakan keputusan investasi perusahaan yang efisien dikarenakan konflik agensi yang terjadi antara investor dengan manajemen tergolong tinggi termasuk pada investor 
institusional. Menurut Saputra \&Wardhani (2017) perusahaan yang dimiliki investor institusional tidak berpengaruh kepada tingkat efisiensi investasi perusahaan. Ketidakmampuan para investor institusional yang memiliki jarak dalam hubungannya dengan perusahaan membuat konsentrasi dan keaktifan pemegang saham institusional terhadap investasi yang dilakukan oleh perusahaan menjadi tidak begitu penting. Sehingga pengendalian perusahaan oleh investor institusional dirasa tidak berjalan efisien. Hal ini dikarenakan tujuan utama dari investor institusional untuk memiliki kepemilikan disuatu perusahaan adalah mengharapkan return dari kinerja perusahaan, sehingga mereka sering kali tidak menempatkan perwakilannya dalam susunan dewan direksi dan komisaris, sehingga pengawasan yang dilakukan oleh investor institusional tidak akan begitu berpengaruh pada keputusan investasi perusahaan.hal ini pun didukung oleh penelitian Fajriani, Wijaya, Widystuti (2021) dan Ujiyanto dan Pramuka (2007) yang menyatakan kepemilikan institusional tidak berpengaruh terhadap efisiensi investasi. Hasil penelitian ini bertolak belakang dengan penelitian Cao et.al (2018) yang menyatakan bahwa kepemilikan institusional meningkatkan efisiensi investasi yang artinya mampu menurunkan agency cost khususnya biaya pengawasan.

\section{Pengaruh Debt Maturity terhadap Efisiensi Investasi}

Berdasarkan hasil uji, debt maturity berpengaruh positif terhadap efisiensi investasi pada perusahaan manufaktur yang terdaftar di BEI tahun 2015-2019. Berdasarkan tabel 5 diketahui bahwa t hitung 8,081 > dari t tabel 1,977 dengan tingkat signifikansi untuk debt maturity 0,000 < 0,05. sehingga H5 diterima, yang berarti variabel debt maturity berpengaruh positif dan signifikan terhadap efisiensi investasi. Hal ini didukung oleh penelitian yang dilakukan Nathaniel \& Butar-butar (2019) yang menyatakan debt maturity berpengaruh positif signfikan terhadap efisiensi investasi. Myers (1997) menyatakan maturitas utang dapat digunakan untuk mengurangi investasi yang berlebihan dan masalah underinvestment. Jika ada proyek NPV positif perusahaan dapat membiayainya dengan utang jangka pendek sehingga mengurangi masalah underinvestment karena utang akan dilikuidasi]dalam waktu singkat dan profitabilitasny $\backslash a$ akan sepenuhnya untuk perusahaan. Selain itu, karena adanya roll-over utang jangka pendek, pemegang utang dapat memantau peminjam dengan lebih baik dan dengan demikian mengurangi konflik keagenan antara kreditor dan peminjam yang timbul dari peluang investasi (Barclay dan Smith, 1995). Dengan adanya komposisi utang jangka pendek perusahaan yang besar, maka mengharuskan perusahaan untuk dapat menjaga likuiditasnya supaya perusahaan dapat memenuhi kewajiban finansialnya, dan hal itu akan menjadikan pihak manajemen tidak mengambil kegiatan investasi secara 
sembarangan. Jadi semakin tinggi maturitas utang maka akan meningkatkan efisiensi investasi perusahaan. Hal ini pun didukung oleh penelitian Hutagalung (2017) dan Christine Yanti (2017) yang menyatakan debt maturity berpengaruh positif signfikan terhadap efisiensi investasi.

\section{KESIMPULAN}

Hasil pengujian dari penelitian ini dapat ditarik kesimpulan bahwa komite audit, kepemilikan manajerial, kepemilikan institusional tidak berpengaruh terhadap efisiensi investasi. Dewan Komisaris Independen dan Debt Maturity berpengaruh positif signifikan terhadap Efisiensi Investasi

\section{Implikasi Manajerial}

Diharapkan hasil penelitian ini dapat dijadikan bahan pertimbangan bagi perusahaan manufaktur yang terdaftar di Bursa Efek Indonesia untuk membuat keputusan investasi yang tepat guna terhindar dari masalah overinvestment atau underinvestment demi tercapainya investasi yang efisien. Bagi investor penelitian ini diharapkan dapat dijadikan sebagai acuan atau pertimbangkan dalam membuat keputusan berinvestasi dengan mempertimbangkan efisiensi investasi suatu perusahaan dan faktor-faktor yang mempengaruhinya seperti tata kelola perusahaan, struktur kepemilikan dan debt maturity.

\section{DAFTAR PUSTAKA}

Abdul, Halim. 2005. Analisis Investasi. Edisi Kedua. Jakarta: Salemba Empat.

Ardiyansah, M. 2004. Pengaruh Corporate Governance, Leverage dan Profitabilitas terhadap Manajemen Laba pada Perusahaan Manufaktur Sektor Industri Barang Konsumsi yang Terdaftar di BEI Periode 2009 - 2013. Universitas Maritim Raja Ali Haji.

Arif, Rahman Hakim. 2011. Pengaruh Likuiditas, Tingkat Inflasi, Pertumbuhan Ekonomi, Car, Roa, Ldr Terhadap Suku Bunga Deposito Berjangka Satu Bulan Pada Bank Umum Indonesiaperiode Tahun 2006-2009. Skripsi Sarjana, Fakultas Ekonomi, Universitas Negeri Yogyakarta.

Barclay, M.J., Smith, C.W., 1995. The Maturity Structure Of Corporate Debt. The Journal Of Finance 50, 609-631.

Butar-Butar, S. 2015. Dampak Kualitas Laporan Keuangan, Regulasi Pengendalian Internal dan Keterbatasan Keuangan Terhadap Inefisiensi Investasi. Jurnal Akuntansi dan Keuangan 17 (1): 57-70.

Cao, Y. et al. (2020). Does Institutional Ownership Improve Firm Investment Efficiency? Emerging Markets Finance and Trade, 56(12), pp. 2772-2792. 
Christine, D., \& Yanti, N. D. (2017). Pengaruh Kualitas Laporan Keuangan Dan Debt Maturity Terhadap Efisiensi Investasi. Forum Keuangan Dan Bisnis Indonesia (Fkbi).

Gomariz, Cutillas M.F., Sánchez Ballesta, J.P., 2013. Financial Reporting Quality, Debt Maturity And Investment Efficiency. Journal Of Banking \& Finance 22, 2-5.

Hutagalung, L. (2017). Hubungan Kualitas Pelaporan Keuangan Dan Debt Maturity Dengan Efisiensi Investasi. Jurnal Akuntansi \& Auditing Indonesia.

Jensen, M., Meckling, W.H., 1976. Theory Of The Firm: Managerial Behaviour, Agency Costs And Ownership Structure. Journal Of Financial Economics 3, 305-360.

Komite Nasional Kebijakan Governance. 2004. Pedoman Tentang Komisaris Independen. https://www.governance-indonesia.or.id/main.htm.

Lai, S. M., Liu, C. L. and Wang, T. (2014) 'Increased disclosure and investment efficiency', Asia-Pacific Journal of Accounting and Economics, 21(3), pp. 308327. doi: 10.1080/16081625.2012.741791.

Lei, Q. and Chen, H. (2019) 'Corporate Governance Boundary, Debt Constraint, and Investment Efficiency', Emerging Markets Finance and Trade, 55(5), pp. 10911108. doi: 10.1080/1540496X.2018.1526078.

Myers, S. C. 1977. Determinants Of Corporate Borrowing. Journal Of Financial Economics. Vol 5. No 2: 147-175.

Nathaniel, A., \& Butarbutar, S. (2019). Determinan Efisiensi Investasi Perusahaan Pubik Di Indonesia. Jurnal Akuntansi Bisnis.

OECD. 2015. OECD Principles Of Corporate Governance. World, 46. Https://Doi.Org/10.1787/9789264015999-En.

Saputra, A. A. D., \& Wardhani, R. (2017). Pengaruh Efektivitas Dewan Komisaris, Komite Audit Dan Kepemilikan Institusional Terhadap Efisiensi Investasi. Jurnal Akuntansi \& Auditing Indonesia.

Scott, William R. 2015. Financial Accounting Theory. Canada: Prentice Hall.

Simanungkalit, E. R. (2017). Pengaruh Tata Kelola Perusahaan Dan Struktur Kepemilikan Terhadap Efisiensi Investasi Perusahaan. Jurnal Akuntansi Bisnis, Universitas Katolik Soegijapranata.

Suwardjono. 2014. Teori Akuntansi Perekayasaan Pelaporan Keuangan, Edisi Ketiga Cetakan Kedelapan.Yogyakarta: Bpfe Yogyakarta. 